
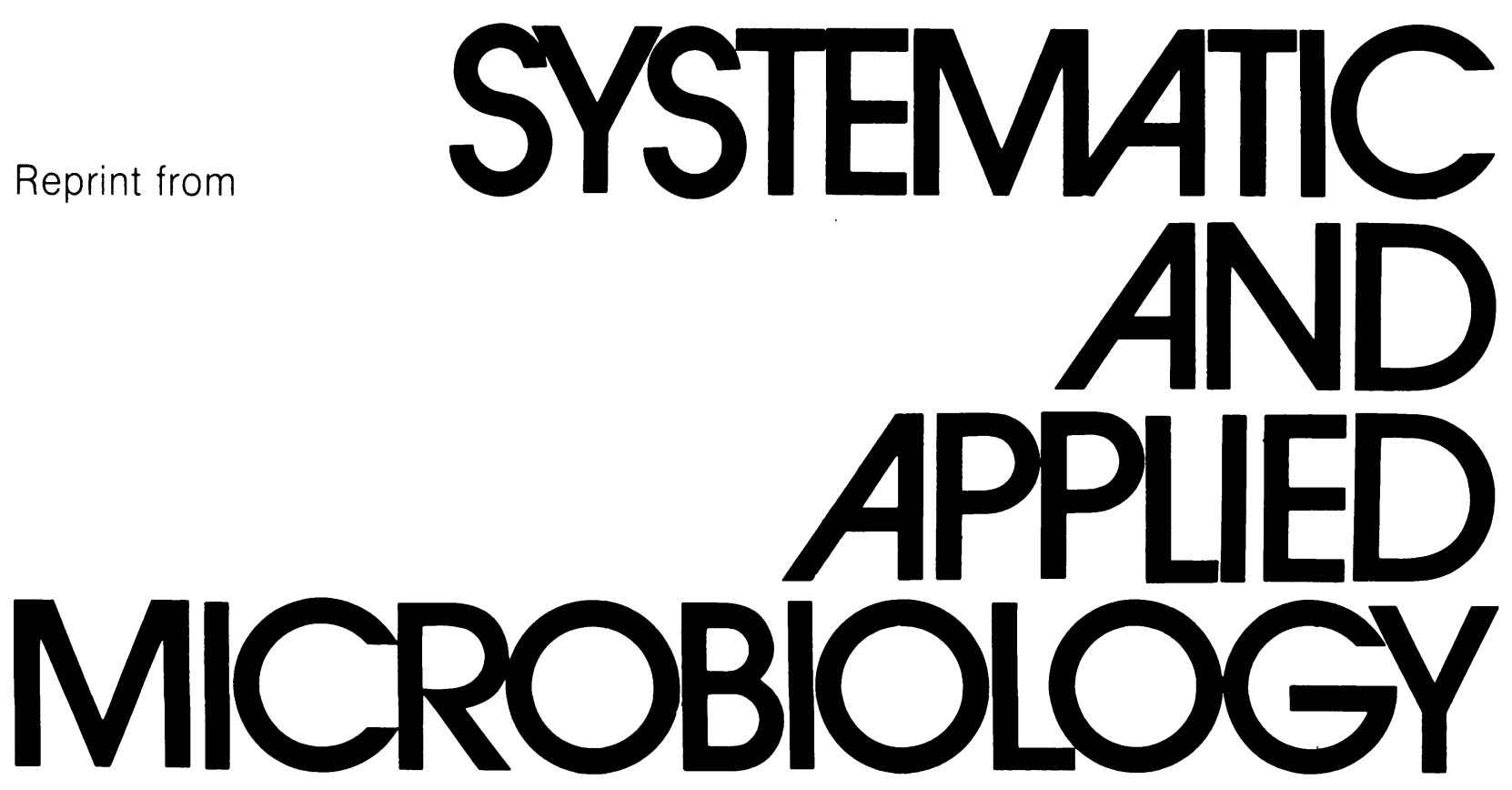

$$
\begin{aligned}
& \text { S. } \\
& \text { Stuttgart - New York }
\end{aligned}
$$





\title{
Sulfolobus metallicus, sp. nov., a Novel Strictly Chemolithoautotrophic Thermophilic Archaeal Species of Metal-Mobilizers
}

\author{
GERTRUD HUBER and KARL O. STETTER* \\ Lehrstuhl für Mikrobiologie der Univerisität Regensburg, 8400 Regensburg, Germany
}

Received May 2, 1991

\begin{abstract}
Summary
Five new isolates of archaeal coccoid thermoacidophiles were obtained from Icelandic solfataric fields. They are strict chemolithoautotrophs gaining energy by oxidation of $\mathrm{S}^{\circ}$ and sulfidic ores. The new strains grow between 50 and $75^{\circ} \mathrm{C}$ and $\mathrm{pH} 1$ and 4.5 and tolerate $\mathrm{NaCl}$ concentrations of up to $3.0 \%$. The GCcontent of their DNA is $38 \mathrm{~mol} \%$.

The new isolates resemble members of Sulfolobus in their morphology, their ability to oxidize reduced sulfur compounds and their GC-content. They are different in their strictly chemolithoautotrophic mode of life, their ore-leaching capacity, DNA/DNA hybridization and incomplete serological cross-reaction of RNA polymerase. Therefore, we describe here a new species, Sulfolobus metallicus. Type strain is Sulfolobus metallicus (Kra 23; DSM 6482).
\end{abstract}

Key words: Sulfolobus metallicus - Sulfolobaceae - Archaea - Leaching - Acidophilic - Chemolithotrophic - Thermophilic

\section{Introduction}

All thermoacidophiles of the archaeal crenarchaeota kingdom are members of the Sulfolobaceae (Stetter, 1989; Woese et al., 1990). Up to now the genera Sulfolobus, Acidianus, Desulfurolobus and Metallosphaera have been described (Brock et al., 1972; Segerer et al., 1986; Zillig et al., 1986; Huber et al., 1989). They share a regular to irregular coccoid shape, the thermoacidophilic mode of life and the ability to oxidize elemental sulfur (Stetter, 1989). In addition, the Sulfolobaceae possess glycoprotein subunit cell envelopes and caldariellaquinone (Weiss, 1974; Zillig et al., 1980; Huber et al., 1989; de Rosa and Gambacorta, 1988). The different genera within the Sulfolobaceae can be distinguished from each other by their metabolic and biochemical properties: Members of Sulfolobus exhibit a GC-content of around $37 \mathrm{~mol} \%$ and are able to utilize sugars, amino acids, and complex organic substances as energy and carbon sources (Brock et al., 1972; Zillig et al., 1980). So far, they have not been found to be able to extract metals (Huber et al., 1989). Acidianus and Desulfurolobus are closely related to each other $(\mathrm{Hu}$ -

* Corresponding author ber et al., 1987). They show a GC-content of about 31 $\mathrm{mol} \%$ and a facultatively aerobic metabolism with elemental sulfur as electron donor or aceeptor (Segerer et al., 1986; Zillig et al., 1986). They are weak ore-leachers (Huber et al., 1989).

The first ore-leaching acidophile, which had been described as Sulfolobus brierleyi, has recently been placed to the genus Acidianus (Brierley and Brierley, 1973; Zillig et al., 1980; Segerer et al., 1986). Metallosphaera is characterized by a GC-content of $45 \mathrm{~mol} \%$ and a strong oreleaching capacity (Huber et al., 1989). The subdivision into the genera on the basis of the metabolic and biochemical properties is further supported by the lack of significant DNA/DNA hybridization and the incomplete serological cross-reaction of their DNA-dependent RNA polymerases between members of them (Stetter, 1989). Within the genus Sulfolobus, the three species $S$. acidocaldarius, $S$. solfataricus and $S$. shibatae can be distinguished from each other by DNA/DNA hybridization (Segerer et al., 1986; Grogan et al., 1990) and by 16S rRNA sequencing (Woese et al., 1984; Olsen et al., 1985; Grogan et al., 1990). 
Here we describe a new group of aerobic metal-mobilizing thermoacidophiles representing a new species within the genus Sulfolobus.

\section{Material and Methods}

Organisms. The type strains of Sulfolobus acidocaldarius (DSM 639), Sulfolobus solfataricus (DSM 1616) and Acidianus brierleyi (DSM 1651) were obtained from the Deutsche Sammlung von Mikroorganismen und Zellkulturen (DSM, Braunschweig, FRG). Sulfolobus shibatae (B12; DSM 5389) was obtained from W. Zillig, Martinsried. Acidianus infernus (DSM 3191) and Metallosphaera sedula (DSM 5348) were obtained from the DSM and had been originally isolated by our laboratory (Segerer et al., 1986; Huber et al., 1989).

Growth conditions. The new isolates and the type strains were grown in modified ALLEN-medium (Allen, 1959; Brock et al., 1972) under shaking (150 rpm). Sulfolobus acidocaldarius, Sulfolobus solfataricus, Sulfolobus shibatae and Acidianus infernus were cultivated at $80^{\circ} \mathrm{C}$, Acidianus brierleyi and Metallosphaera sedula at $65^{\circ} \mathrm{C}$. The isolates were routinely grown at $65^{\circ} \mathrm{C}$ on ore mixture "G6" (Huber et al., 1989). The cultures were usually transferred into fresh medium after one week of incubation $(5 \%$ inoculum). Mobilization of metal ions was determined in $500 \mathrm{ml}$ Erlenmeyer flasks containing $120 \mathrm{ml}$ culture medium and $4 \mathrm{~g}$ ore mixture "G1N" equipped with an air condensor (Huber et al., 1989).

Growth measurement. Bacterial growth was followed by direct cell counting in a Thoma chamber (depth $0.02 \mathrm{~mm}$ ) under a phase contrast light microscope (Zeiss Standard 16).

Electron microscopy. Pt-shadowed cells and thin sections were prepared and electron microscopy was carried out according to König and Stetter (1982).

Substrate utilization. In order to determine the substrates of the new isolates, the same organic and inorganic substances were assayed as described earlier (Huber et al., 1989). In addition, growth on the amino acids DL-alanine, DL-valine, L-methionine and L-glutamic acid $(10 \mathrm{~g} / \mathrm{l})$ was examined.

Tolerance against heavy metal ions. Resistance against various heavy metal ions during growth on ore mixture "G6" was tested according to Huber et al. (1989).

Determination of metabolic products. Mobilization of metal ions from the ores and production of sulfate from elemental sulfur was measured in the supernatant of the cultures by "ICP" (Inductively Coupled Plasma, JY 70 Plus, Jobin Yvon) analyses.

Lipid analyses. Lipids were extracted according to the method of de Rosa et al. (1983). The total lipids were fractionated and identified as described previously (Huber et al., 1989).

Isolation of DNA. The DNA was prepared according to Wildgruber et al. (1982).

DNA base composition. The GC-content of DNA was determined by melting point analysis (Marmur and Doty, 1962) and by high performance liquid chromatography (HPLC) after digestion of the DNA with nuclease P1 (Zillig et al., 1980).

DNA similarity. DNA/DNA hybridization was performed as described elsewhere (König, 1984).

DNA-dependent RNA polymerase. The RNA polymerases of S. acidocaldarius and isolate $\mathrm{Kra} 23$ were purified according to Zillig et al. (1979). The activity was assayed for $20 \mathrm{~min}$ at $55^{\circ} \mathrm{C}$ with poly[d(A-T)] as a template (Zillig et al., 1979). Exponential gradient SDS polyacrylamide gels $(5-25 \%)$ were prepared according to Laemmli (1970) and Mirault and Scherrer (1971). The immunochemical cross-reaction of the RNA polymerase of isolate Kra23 was assayed as described by Ouchterlony (1962) employing rabbit antibodies (Stetter, 1977).

\section{Results}

\section{Collection of samples and isolation of the new bacteria}

Eleven aerobic samples were collected from water- and mudholes of terrestric Icelandic solfataric fields within the Krafla, Kerlingarfjöll, Krisuvik, Namarskarth and Hveragerthi areas. The original temperatures were between 55 and $100{ }^{\circ} \mathrm{C}$ and the $\mathrm{pH}$ between 1.5 and 5.0. All samples were carried to the laboratory without $\mathrm{pH}$ - and temperature control and were stored there at $4{ }^{\circ} \mathrm{C} .1 \mathrm{ml}$ of each of the original samples was transferred into $30 \mathrm{ml}$ of mineral medium, $\mathrm{pH} 2.0$ supplemented with pyrite, chalcopyrite or the ore mixture "G1N". After one week of incubation at 65 or $75^{\circ} \mathrm{C}$ under shaking (150 rpm), irregular coccoid organisms, resembling Sulfolobus in shape, became visible within five (Kra23, Kra22, Ker2, NA4, Okri3) of the culture attempts from the samples of the Krafla, Kerlingarfjöll, Namarskarth and Krisuvik solfatares. Pure cultures were obtained by repeated serial dilutions in ore-containing (mixture "G1N") media.

\section{Morphology}

In the light microscope, cells of the new isolates appeared as irregular, lobed cocci about $1.5 \mu \mathrm{m}$ in diameter, sometimes reminiscent of pyramids or dishes (Fig. 1). The cells appeared immotile and occurred singly or in pairs (Fig. 2). They were surrounded by an envelope consisting most likely of protein subunits (Fig. 2).

\section{Storage}

Cultures frozen and stored over liquid nitrogen at $-140^{\circ} \mathrm{C}$ served as inocula for at least one year.

\section{Optimal growth conditions}

Growth on ores was obtained between 50 and $75^{\circ} \mathrm{C}$ with an optimum around $65^{\circ} \mathrm{C}$ (Kra23; doubling time 13 h) or $70^{\circ} \mathrm{C}$ (Ker2; doubling time $8 \mathrm{~h}$ ) (Fig. 3). The isolates grew in a $\mathrm{pH}$ range between 1.0 and 4.5 (not shown) and tolerated $\mathrm{NaCl}$ concentrations of up to $3.0 \%$. Optimal growth (doubling time $8 \mathrm{~h}$; final cell density about $2 \times$ $10^{8} / \mathrm{ml}$ ) was observed at $\mathrm{NaCl}$ concentrations between 0

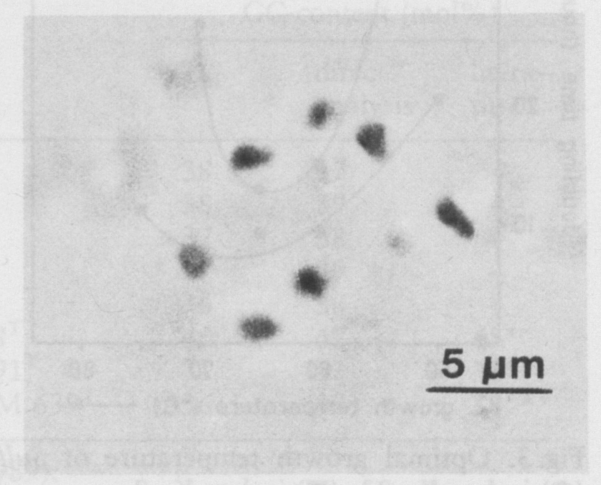

Fig. 1. Phase contrast micrograph of cells of Sulfolobus metallicus (isolate $\mathrm{Kra23}$ ). Bar $5 \mu \mathrm{m}$. 


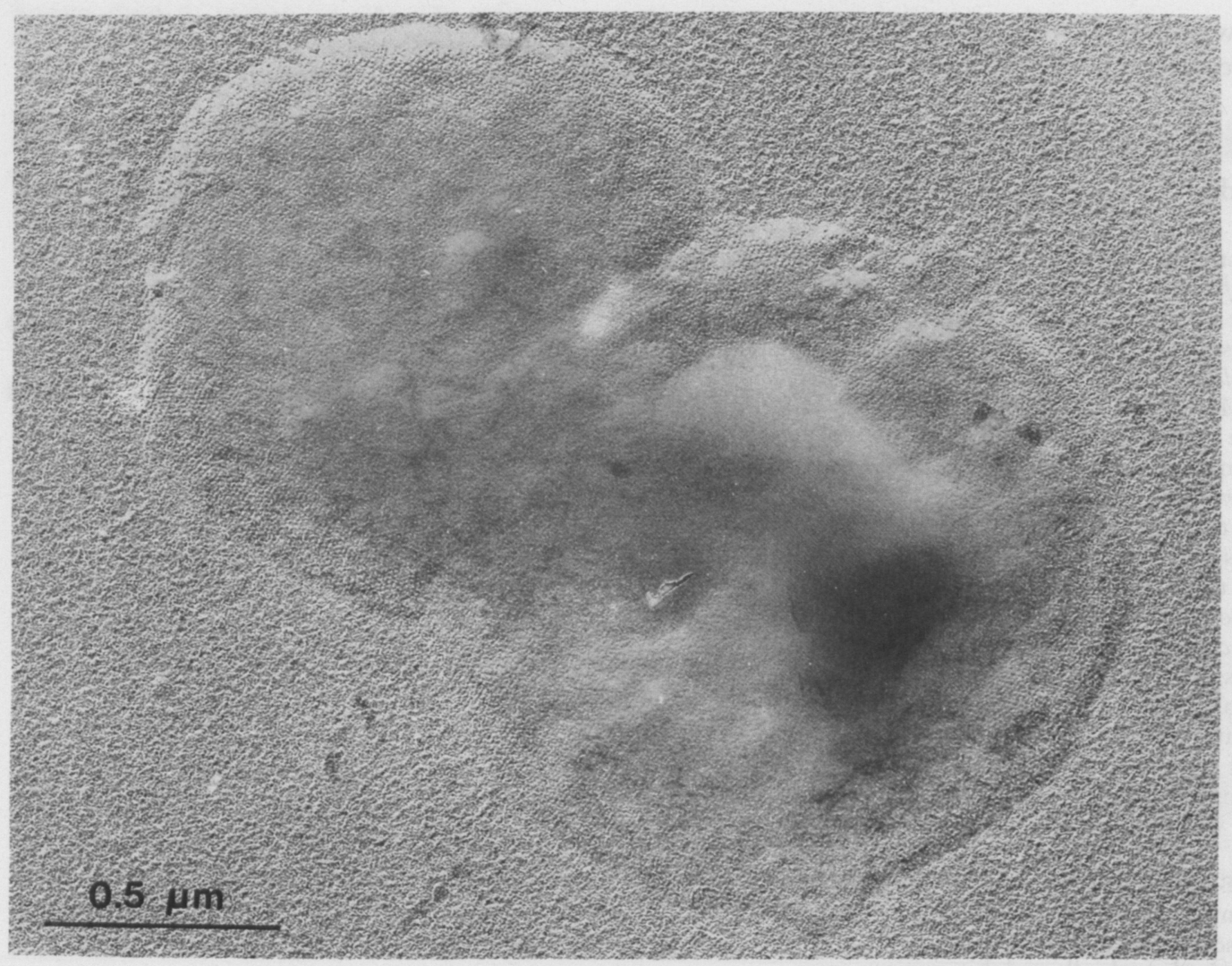

Fig. 2. Electron micrograph of Sulfolobus metallicus (isolate Kra23), platinum shadowed. Bar $0.5 \mu \mathrm{m}$.

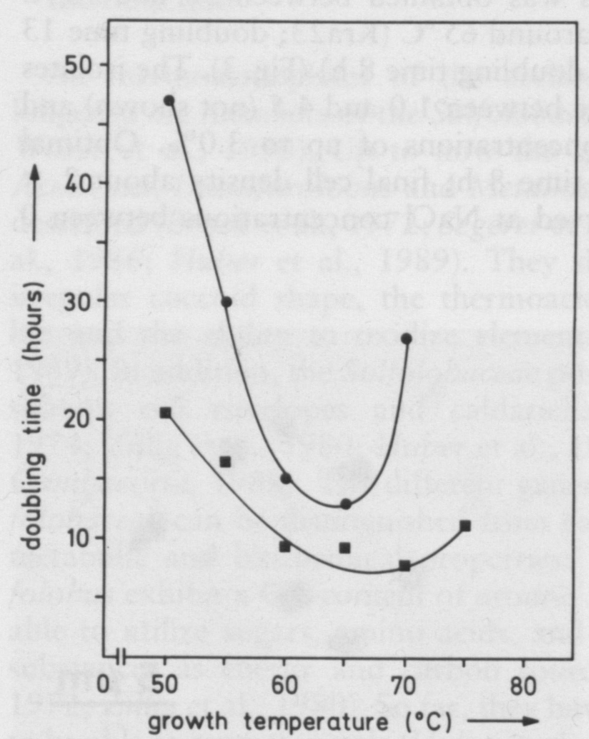

Fig. 3. Optimal growth temperature of Sulfolobus metallicus. (ט) isolate $\mathrm{Kra} 23$; ( $)$ isolate $\mathrm{Ker} 2$.

The doubling times were calculated from the slopes of the growth curves (not shown).

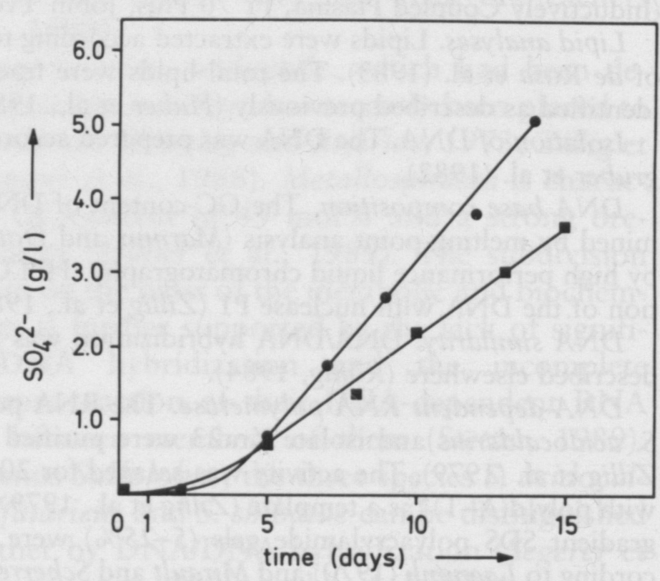

Fig. 4. Sulfate formation of Sulfolobus metallicus during growth on elemental sulfur.

(•) isolate $\mathrm{Kra23}$; ( ) isolate Ker2. 
and $0.75 \%$. S. acidocaldarius and S. solfataricus did not grow in the presence of 0.5 and $0.75 \% \mathrm{NaCl}$, respectively (not shown).

\section{Metabolism}

The new isolates grew chemolithoautotrophically by the oxidation of elemental sulfur, single sulfidic ores (pyrite, chalcopyrite, sphalerite) and on the ore mixtures "G6" and "GIN". They were even able to grow on the synthetic sulfides $\mathrm{ZnS}$ and $\mathrm{CdS}$. On elemental sulfur within two weeks the isolates $\mathrm{Kra} 23$ and $\mathrm{Ker} 2$ formed $5100 \mathrm{mg} / \mathrm{l}$ and $3700 \mathrm{mg} / \mathrm{l}$ sulfate, respectively (Fig. 4). Sulfuric acid formation was not stimulated by the addition of $0.005 \%$ yeast extract (not shown). Arsenopyrite, bornite, cinnabar, chalcocite, covellite and the synthetic sulfides $\mathrm{CuS}, \mathrm{FeS}$, $\mathrm{MoS}_{2}, \mathrm{Sb}_{2} \mathrm{~S}_{3}$ and $\mathrm{SnS}$ did not serve as substrates. No growth was obtained on beef extract, casamino acids, peptone, tryptone and yeast extract, on arabinose, fructose, galactose, glucose, lactose, mannose, raffinose, ribose, sucrose, sorbose and xylose and on alanine, glutamic acid, methionine and valine. Under anaerobic conditions no growth and sulfur reduction by isolate $\mathrm{Kra} 23$ was observed (A. Segerer, pers. comm.).

\section{Heavy metal resistance}

During growth on the ore mixture "G6", the isolate $\mathrm{Kra} 23$ tolerated concentrations of $1.7 \mathrm{mmol} / \mathrm{l}$ cobalt $(M$. sedula $0.85 \mathrm{mmol} / \mathrm{l}$ ), $300 \mathrm{mmol} / \mathrm{h}$ zinc (M. sedula 150 $\mathrm{mmol} / \mathrm{l}$ ) and $17 \mathrm{mmol} / \mathrm{h}$ nickel ions (M. sedula $1.7 \mathrm{mmol} / \mathrm{l}$ ) (Table 1). For $S$. acidocaldarius, a tolerance against arsenate of $10 \mathrm{mmol} / \mathrm{h}$ was reported (Lindström and Sehlin 1989), which is in the range of isolate Kra23. Non metalmobilizing bacteria, e.g. E. coli, are inhibited by a 30,000 fold lower copper ion concentration $(0.5 \mu \mathrm{mol} / /)$ than isolate Kra23 (Domek et al., 1984).

\section{Ore leaching capacity}

All isolates mobilized 90 to $100 \%$ of the total copper within four weeks (Table 2). The final zinc ion concentrations in the supernatant varied between 70 and $100 \%$ depending on the strain (Table 2). $100 \%$ of the uranium were mobilized by all isolates within 2 weeks with the exception of strain Kra22.

\section{Lipid composition}

The isolates Kra23 and Kra22 contained glycerol-dialkyl-nonitol tetraethers and caldariellaquinone in the membrane. Sulfolobusquinone and tricyclicquinone were not found. Between the two new strains only little differences in the proportions of minor complex lipids were detectable (M. de Rosa and A. Gambacorta, pers. comm.).

\section{GC-content of the DNA}

The GC-content of all isolates was around $38 \mathrm{~mol} \%$ (Table 3). The type species of the different genera within the Sulfolobaceae served as references (Table 3).
Table 1. Growth of S.metallicus (isolate Kra23) and Metallosphaera sedula on ore mixture "G6" in the presence of different heavy metal ion concentrations (in $\mathrm{mmol} / \mathrm{l}$ )

\begin{tabular}{|c|c|c|c|c|}
\hline \multirow{3}{*}{ Metal ion } & \multicolumn{4}{|c|}{ Strain } \\
\hline & \multicolumn{2}{|c|}{ Kra23 } & \multicolumn{2}{|c|}{ M. sedula* } \\
\hline & growth & no growth & growth & no growth \\
\hline $\mathrm{Ag}$ & 0.09 & 0.9 & 0.09 & 0.9 \\
\hline As & 1.3 & 13 & 1.3 & 13 \\
\hline $\mathrm{Cd}$ & 0.9 & 9 & 0.9 & 9 \\
\hline Co & 1.7 & 17 & 0.85 & 1.7 \\
\hline $\mathrm{Cu}$ & 16 & 160 & 16 & 79 \\
\hline $\mathrm{Hg}$ & 0.05 & 0.5 & 0.05 & 0.5 \\
\hline Mo & 1 & 10 & 1 & 10 \\
\hline $\mathrm{Ni}$ & 17 & 170 & 1.7 & 17 \\
\hline $\mathrm{Sb}$ & 0.8 & 8 & 0.8 & 8 \\
\hline $\mathrm{U}$ & 0.4 & 4 & 0.4 & 4 \\
\hline $\mathrm{Zn}$ & 300 & 750 & 150 & 750 \\
\hline
\end{tabular}

* Data from Huber et al. (1989).

Table 2. Metal extraction by the new isolates from the ore mixture "G1N" within 28 days $(\mathrm{mg} / \mathrm{l})$

\begin{tabular}{llll}
\hline Extraction by & \multicolumn{3}{c}{ Metal } \\
\cline { 2 - 4 } & $\mathrm{Cu}$ & $\mathrm{U}$ & $\mathrm{Zn}$ \\
\hline Kra23 & 700 & 94 & 4125 \\
$\mathrm{Kra22}$ & 700 & 60 & 3000 \\
NA4 & 770 & 90 & 3900 \\
Ker2 & 760 & 87 & 4025 \\
Okri3 & 700 & 90 & 4500 \\
sterile control* & 90 & 65 & 1300 \\
\hline "G1N" metal ion content * & 800 & 95 & 4500 \\
\hline
\end{tabular}

* Sterile control: $\mathrm{pH} 2.5,65^{\circ} \mathrm{C}$.

* Determined by chemical extraction of ore mixture G1N with concentrated aqua regia.

Table 3. DNA base composition of the isolates and of representatives of the Sulfolobaceae

\begin{tabular}{lccc}
\hline Strain & \multicolumn{3}{c}{ GC-content (mol\%) } \\
\cline { 2 - 4 } & $\mathrm{T}_{\mathrm{M}}$ & $\begin{array}{l}\text { direct } \\
\text { analysis }\end{array}$ & $\begin{array}{l}\text { litera- } \\
\text { ture }\end{array}$ \\
\hline Kra23 & 38 & 37 & - \\
Kra22 & 38 & 39 & - \\
NA4 & 37 & 38 & - \\
Ker2 & 37 & 39 & - \\
Okri3 & 36 & 38 & - \\
M. sedula DSM 5348 & \\
A. infernus DSM 3191 & 45 & 47 & $45^{\text {T }}$ \\
S.acidocaldarius DSM $639^{\mathrm{T}}$ & 31 & 33 & $31^{* *}$ \\
\hline
\end{tabular}

* Huber et al. (1989).

* * Segerer et al. (1986).

*** Zillig et al. (1980). 


\begin{tabular}{|c|c|c|c|c|c|}
\hline \multirow{2}{*}{$\begin{array}{l}\text { Filter-bound } \\
\text { DNA from }\end{array}$} & \multicolumn{5}{|c|}{${ }^{32}$ P-labelled DNA from } \\
\hline & $\begin{array}{l}\text { A. brier- } \\
\text { leyi } \\
\text { DSM } 1651^{\mathrm{T}}\end{array}$ & $\begin{array}{l}\text { S.acido- } \\
\text { caldarius } \\
\text { DSM } 639^{\mathrm{T}}\end{array}$ & $\begin{array}{l}\text { S. solfata- } \\
\text { ricus } \\
\text { DSM } 1616^{\mathrm{T}}\end{array}$ & $\begin{array}{l}\text { M. sedula } \\
\text { DSM } 5348^{\mathrm{T}}\end{array}$ & $\begin{array}{l}\text { Kra23 } \\
\text { DSM } 6482^{\mathrm{T}}\end{array}$ \\
\hline A. brierleyi & 100 & 5 & 9 & 7 & 7 \\
\hline A. infernus & 6 & 3 & 5 & 6 & 8 \\
\hline S. acidocaldarius & 4 & 100 & 12 & 12 & 9 \\
\hline S. solfataricus & 7 & 9 & 100 & 8 & 7 \\
\hline M. sedula & 12 & 8 & 10 & 100 & 5 \\
\hline Kra23 & 5 & 3 & 6 & 6 & 100 \\
\hline
\end{tabular}

Table 4. DNA/DNA similarity between Sulfolobus metallicus (isolate Kra23) and the type strains of the Sulfolobaceae (in \%)

\section{Sensitivity to diphtheria toxin}

In the crude extracts of isolates Kra23 and NA4, an elongation factor II-like protein was ADP-ribosylated by diphtheria toxin (F. Klink, pers. comm.; Kessel and Klink, 1980).

\section{DNA/DNA similarity}

All new isolates exhibited DNA similarity between 73 and $100 \%$ among each other (not shown). No significant hybridization between strain Kra23 as a representative of this group and the type species of the different genera within the Sulfolobaceae was observed (Table 4) indicating phylogenetic distance.

\section{DNA-dependent RNA polymerase}

The molecular masses of the polypeptides (between 130 and $11 \mathrm{kD}$ ) of the Kra23 RNA polymerase were determined by coelectrophoresis with the $S$. acidocaldarius enzyme (Table 5). In order to investigate the immunological

Table 5. Molecular masses (in kilo daltons) of the subunits of the DNA-dependent RNA polymerases of Sulfolobus metallicus (isolate Kra23) and Sulfolobus acidocaldarius

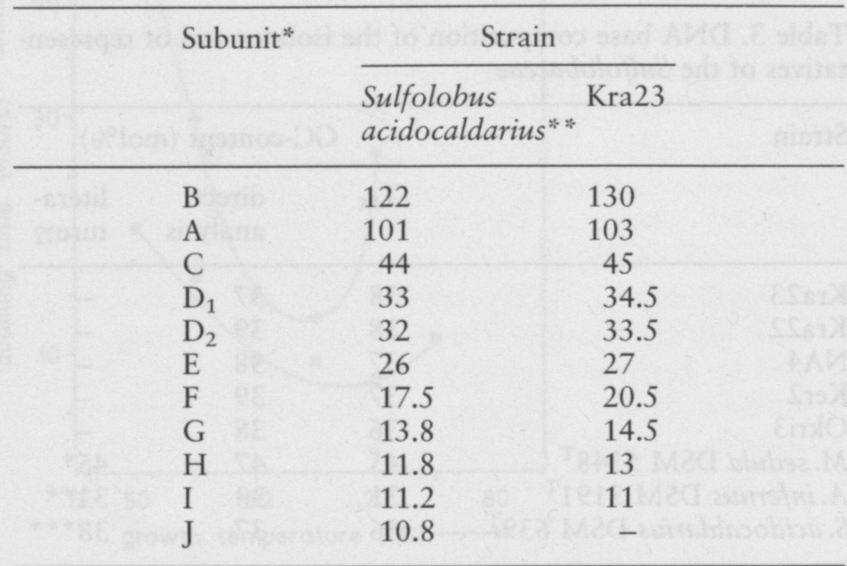

* Designations in analogy to S.acidocaldarius following the molecular sizes.

** Molecular weights according to Prangishvilli et al. (1982). relationships of the RNA polymerase of isolate Kra23 to other thermoacidophilic sulfur-metabolizers, antibodies against the enzyme of strains Kra23 were prepared (Stetter, 1977). In the Ouchterlony immunodiffusion assay, the enzymes of $S$. acidocaldarius, $S$. solfataricus and $A$. brierleyi spurred against that of isolate Kra23 (Fig. 5). As expected from the DNA homology, the RNA polymerase of strain Okri3 showed immunochemical identity with that of strain Kra23 (Fig. 5).

\section{Discussion}

The five new isolates belong to the archaeal domain in that they contain isopranyl ether lipids (de Rosa et al.,

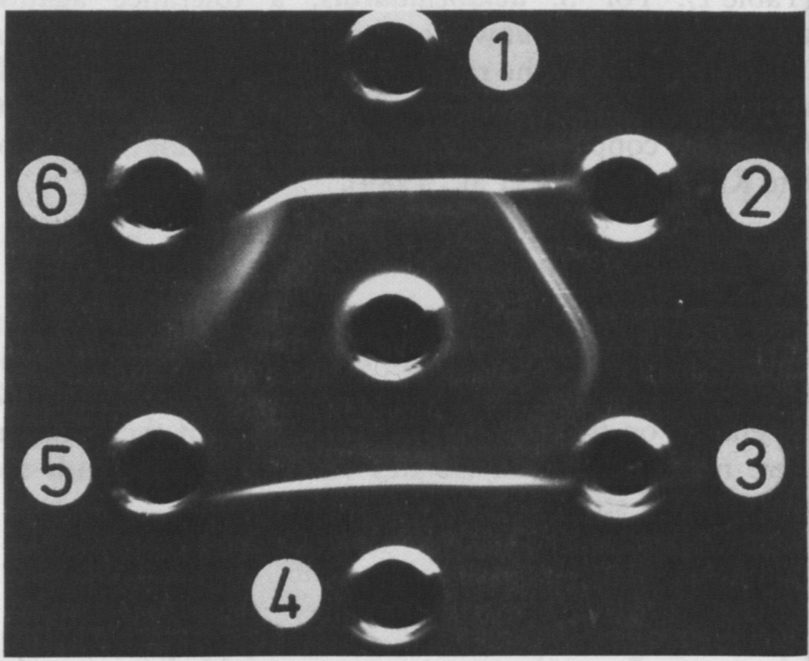

Fig. 5. Ouchterlony immunodiffusion test of Sulfolobus metallicus (isolate Kra23) RNA polymerase antibodies against the DNA-dependent RNA polymerases of members of the Sulfolobaceae.

(center) antibodies against the DNA-dependent RNA polymerase of Sulfolobus metallicus (isolate Kra23)

Purified or enriched RNA polymerases of:

$(1,4)$ Sulfolobus metallicus (isolate Kra23), purified

(2) Sulfolobus acidocaldarius, purified

(3) Metallosphaera sedula, purified

(5) Acidianus brierleyi, enriched

(6) Sulfolobus metallicus (isolate Okri 3), enriched 
1977; Langworthy et al., 1982; de Rosa and Gambacorta, 1988), possess an elongation factor II-like protein sensitive against diphtheria toxin (Kessel and Klink, 1982) and exhibit a complex subunit structure of their DNA-dependent RNA polymerase (Zillig et al., 1980; Zillig et al., 1982). On the basis of their irregular coccoid shape, their thermoacidophilic mode of life, their aerobic metabolism and their ability to oxidize elemental sulfur, they are members of the Sulfolobaceae (Stetter, 1989). Furthermore they resemble the members of this family in their possession of glycerol-dialkyl-nonitol tetraethers and of caldariellaquinone in their membrane (de Rosa and Gambacorta, 1988). In their GC-content of around $38 \mathrm{~mol} \%$, the new isolates are similar to $S$. acidocaldarius, $S$. solfataricus and $S$. shibatae. However they can be distinguished from these species by their obligately chemolithoautotrophic mode of nutrition and their leaching capacity. Further differences are their salt tolerance, lack of DNA/DNA similarity and the incomplete cross-reaction of antibodies against the DNA-dependent RNA polymerase of isolate $\mathrm{Kra} 23$ with the enzymes of $S$. acidocaldarius and $S$. solfataricus. Therefore we consider the new isolates as representatives of a new species of the genus Sulfolobus, which we name Sulfolobus metallicus, because of their ability, to mobilize metal ions from sulfidic ores. Due to their equal metabolic properties, the identical GC-content and a DNA homology of more than $73 \%$ between each other (Schleifer and Stackebrandt, 1983), all five isolates are members of the new species $S$. metallicus. In their ability to mobilize metals from sulfidic ores, $S$. metallicus resembles the genera Acidianus and Metallosphaera. In contrast to the Acidianus species however, $S$. metallicus is unable to reduce elemental sulfur under anaerobic conditions. In addition, the GC-content of the DNA of $S$. metallicus is around $7 \%$ higher than that of the type strains Acidianus infernus (31 mol\%) and $7 \%$ lower than that of Metallosphaera sedula $(45 \mathrm{~mol} \%)$. The phylogenetic distance of $S$. metallicus to the genera Acidianus and Metallosphaera is further evident by the lack of significant DNA homology (Schleifer and Stackebrandt, 1983) and the incomplete immunological cross-reaction of antiserum against the native RNA polymerase of isolate Kra23 (Stetter et al., 1981). So far, members of $S$. metallicus were only isolated from samples of terrestric Icelandic solfataric fields. Because of their salt tolerance of up to $3 \% \mathrm{NaCl}$, however, geothermally heated acidic marine environments could possibly be another biotope.

\section{Description of Sulfolobus metallicus, sp. nov.}

me.tal'li.cus. L. masc. n. metallicus, the miner.

Gram-negative irregular cocci about $1.5 \mu \mathrm{m}$ in width. Growth between 50 and $75^{\circ} \mathrm{C}$, at $\mathrm{pH} 1.0$ to 4.5 and at 0 to $3 \% \mathrm{NaCl}$. Aerobic. Obligately chemolithoautotrophic growth on sulfidic ores like pyrite, sphalerite and chalcopyrite and on elemental sulfur. Formation of sulfuric acid. No sulfur reduction anaerobically. Cell envelope consists of a S-layer. Isopranyl ether lipids and caldariellaquinone present. An elongation factor II-like protein is sensitive to diphtheria toxin. DNA base composition 38 mol\% GC. DNA similarity below $9 \%$ to the type strains of the genera Acidianus, Metallosphaera and Sulfolobus. "BAC" type DNA-dependent RNA polymerase with molecular masses of the polypeptides of $130,103,45$, $34.5,33.5,27,20.5,14.5,13$ and $11 \mathrm{kD}$ (determined by SDS polyacrylamide gel electrophoresis). Incomplete cross-reaction of antibodies against the native RNA polymerase of isolate Kra23 with RNA polymerases of the type strains of Acidianus infernus Metallosphaera sedula and Sulfolobus acidocaldarius.

Isolated from continental solfataric fields in Iceland.

Type strain: Sulfolobus metallicus, Kra 23, DSM 6482, Braunschweig, FRG.

Acknowledgements. The excellent technical assistance of Lucia Schwarzfischer and Silvia Sur is greatly appreciated. We wish to thank the Icelandic government for a research permit and Jakob Kristjansson for helpful guidence in Icelandic solfatara fields. Furthermore we wish to thank F. Klink, M. de Rosa and A. Gambacorta for providing unpublished data and C. Spinnler for results on RNA polymerases.

This work was supported by grants of the Bundesministerium für Forschung und Technologie (BMFT, Projektleitung Rohstoffforschung, Förderungskennzeichen $03 \mathrm{C} 1420$ and 03 R $085 \mathrm{~A}$ 2) and by the Fonds der Chemischen Industrie.

\section{References}

Allen, M. B.: Studies with Cyanidium caldarium, an anomalously pigmented chlorophyte. Arch. Microbiol. 32, 270-277 (1959)

Brierley, C. L., Brierley, J. A.: A chemoautotrophic and thermophilic microorganism isolated from an acid hot spring. Can. J. Microbiol. 19, 183-188 (1973)

Brock, T. D., Brock, K. M., Belley, R. T., Weiss, R. L.: Sulfolobus: A new genus of sulfur-oxidizing bacteria living at low $\mathrm{pH}$ and high temperature. Arch. Microbiol. 84, 54-68 (1972)

De Rosa, M., Gambacorta, A.: The lipids of archaebacteria. Progr. Lipid Res. 27, 153-175 (1988)

De Rosa, M., De Rosa, S., Gambacorta, A., Minale, L., Thomson, $R$. H., Worthington, $R$. D.: Caldariellaquinone, a unique benzo-b-thiophen-4,7-quinone from Caldariella acidophila, an extremely thermophilic and acidophilic bacterium. J. Chem. Soc. Perkin. Trans. 1, 653-657 (1977)

De Rosa, M., Gambacorta, A., Nicolaus, B., Chappe, B., Albrecht, $P$.: Isoprenoid ethers; backbone of complex lipids of the archaebacterium Sulfolobus solfataricus. Biochim. Biophys. Acta $753,249-256$ (1983)

Domek, M. J., LeChevallier, M. W., Cameron, S. C., McFeters, G. A.: Evidence for the role of copper in the injury process of coliform bacteria in drinking water. Appl. Environ. Microbiol. 48, 289-293 (1984)

Grogan, D., Palm, P., Zillig, W.: Isolate B12, which harbours a virus-like element, represents a new species of the archaebacterial genus Sulfolobus, Sulfolobus shibatae, sp. nov. Arch. Mirobiol. 154, 594-599 (1990)

Huber, R., Huber, G., Segerer, A., Stetter, K. O.: Aerobic and anaerobic extremely thermophilic autotrophs, pp. 44-51. In: Microbial growth on $\mathrm{C}_{1}$ compounds. Proceedings of the 5 th International Symposium $(H$. W. van Verseveld, J. A. Duine, eds.). Dordrecht, M. Nijhoff Publ. 1987

Huber, G., Spinnler, C., Gambacorta, A., Stetter, K. O.: Metallosphaera sedula gen. and sp. nov. represents a new genus of aerobic, metal-mobilizing, thermoacidophilic archaebacteria. System. Appl. Microbiol. 12, 38-47 (1989) 
Kessel, M., Klink, F.: Archaebacterial elongation factor is ADPribosylated by diphtheria toxin. Nature 287, 250-251 (1980)

Kessel, M., Klink, F.: Identification and comparison of eighteen archaebacteria by means of the diphtheria toxin reaction. $\mathrm{Zbl}$. Bakt. Hyg., I. Abt. Orig. C 3, 140-148 (1982)

König, H.: Isolation and characterization of Methanobacterium uliginosum sp. nov. from a marshy soil. Can. J. Microbiol. 30, 1477-1481 (1984)

König, H., Stetter, K. O.: Isolation and characterization of Methanolobus tindarius, sp. nov., a coccoid methanogen growing only on methanol and methylamines. Zbl. Bakt. Hyg., I. Abt. Orig. C 3, 478-490 (1982)

Laemmli, U. K.: Cleavage of structural proteins during the assembly of the head of bacteriophage T4. Nature 227, 680-685 (1970)

Langworthy, T. A., Tornabene, T. G., Holzner, G.: Lipids of archaebacteria. Zbl. Bakt. Hyg., I. Abt. Orig. C 3, 228-244 (1982)

Lindström, E. B., Sehlin, H. M.: Toxicity of arsenic compounds to the sulphur-dependent archaebacterium Sulfolobus, pp. 59-70. In: Biohydrometallurgy (J. Salley, R. G. L. McCready, P. L. Wichlacz, eds.). CANMET 1989

Marmur, J., Doty, P.: Determination of the base composition of deoxyribonucleic acid from its thermal denaturation temperature. J. Molec. Biol. 5, 109-118 (1962)

Mirault, M. E., Scherrer, K.: Isolation of preribosomes from Hela cells and its characterization by electrophoresis on uniform and exponential gradient polyacrylamide gels. Eur. J. Biochem. 23, 372-384 (1971)

Olsen, G. J., Pace, N. R., Nuell, M., Kaine, B. P., Gupta, R., Woese, C. R.: Sequence of the $16 \mathrm{~S}$ rRNA gene from the thermoacidophilic archaebacterium Sulfolobus solfataricus and its evolutionary implications. J. Molec. Evol. 22, 301-307 (1985)

Ouchterlony, Ö.: Diffusion-in-gel methods for immunological analysis II, pp. 30-154. In: Progress in allergy (P. Kallod, B. H. Waksman, eds.), Vol. VI. Basel, Karger 1962

Prangishvilli, D., Zillig, W., Gierl, A., Biesert, L., Holz, I.: DNAdependent RNA polymerases of thermoacidophilic archaebacteria. Eur. J. Biochem. 122, 471-477 (1982)

Schleifer, K. H., Stackebrandt, E.: Molecular systematics of prokaryotes. Ann. Rev. Microbiol. 37, 143-187 (1983)

Segerer, A., Neuner, A., Kristiansson, J. K., Stetter, K. O.. Acidianus infernus gen. nov., sp. nov., and Acidianus brierleyi comb. nov.: facultatively aerobic, extremely acidophilic ther- mophilic sulfur-metabolizing archaebacteria. Int. J. System. Bact. 36, 559-564 (1986)

Stetter, K. O.: Transcription in Lactobacillaceae: DNA-dependent RNA polymerase from Lactobacillus casei. Isolation of transcription factor y. Hoppe-Seyler's Z. physiol. Chem. 358, 1093-1104 (1977)

Stetter, K. O.: Order III. Sulfolobales ord. nov., pp. 2250-2253. In: Bergey's Manual of Systematic Bacteriology, Vol. 3 (J. T. Staley, M. P. Bryant, N. Pfennig, J. G. Holt, eds.), 9th ed. Baltimore-Hong Kong-London-Sydney, Williams \& Wilkins 1989

Stetter, K. O., Thomm, M., Winter, J., Wildgruber, G., Huber, H., Zillig, W., Janécovic, D., König, H., Palm, P., Wunderl, S.: Methanothermus fervidus, sp. nov., a novel extremely thermophilic methanogen isolated from an Icelandic hot spring. Zbl. Bakt. Hyg., I. Abt. Orig. C 2, 166-178 (1981)

Weiss, R. L.: Subunit cell wall of Sulfolobus acidocaldarius. J. Bact. 118, 275-284 (1974)

Wildgruber, G., Thomm, M., König, H., Ober, K., Ricchiuto, Th., Stetter, K. O.: Methanoplanus limicola, a plate-shaped methanogen representing a novel family, the Methanoplanaceae. Arch. Microbiol. 132, 31-36 (1982)

Woese, C. R., Gupta, R., Hahn, C. M., Zillig, W., Tu, J.: The phylogenetic relationships of three sulfur dependent archaebacteria. System. Appl. Microbiol. 5, 97-105 (1984)

Woese, C. R., Kandler, O., Wheelis, M. L.: Towards a natural system of organism: proposal for the domains Archaea, Bacteria and Eucarya. Proc. Natl. Acad. Sci. USA 87, 4576-4579 (1990)

Zillig, W., Stetter, K. O., Janékovic, D.: DNA-dependent RNA polymerase from the archaebacterium Sulfolobus acidocaldarius. Eur. J. Biochem. 96, 597-604 (1979)

Zillig, W., Stetter, K. O., Wunderl, S., Schulz, W., Priess, H., Scholz, I.: The Sulfolobus "Caldariella" group: taxonomy on the basis of the structure of DNA-dependent RNA polymerases. Arch. Microbiol. 125, 259-269 (1980)

Zillig, W., Stetter, K. O., Schnabel, R., Madon, J., Gierl, A.: Transcription in Archaebacteria. Zbl. Bakt. Hyg., I. Abt. Orig. C 3, 218-227 (1982)

Zillig, W., Yeats, S., Holz, I., Boeck, A., Rettenberger, M., Gropp, F., Simon, G.: Desulfurolobus ambivalens, new genus new species, an autotrophic archaebacterium facultatively oxidizing or reducing sulfur. System. Appl. Microbiol. 8, 197-209 (1986)

Professor Dr. K. O. Stetter, Lehrstuhl für Mikrobiologie der Universität Regensburg, Universitätsstr. 31, D-8400 Regensburg 